\title{
Outcome of Epidemiological Investigation of COVID-19 Outbreak in a South West State of Nigeria, March to August 2020
}

\author{
Elvis Efe Isere ${ }^{*}\left(\mathbb{D}\right.$, Adewale Moses Adejugbagbe ${ }^{1^{*}}{ }^{\mathbb{C}}$, Aderonke Tolulope Fagbemi2, \\ Stephen Fagbemi ${ }^{3}$, Adekunle Gboyega Famokun ${ }^{3,4}$, Temitope Olajumoke Omoju ${ }^{3,4}{ }^{(\mathbb{B}}$, \\ Wahab Adegbenro ${ }^{3}$
}

\author{
${ }^{1}$ Department of Epidemiology and Medical Statistics, University of Ibadan, Ibadan, Nigeria \\ ${ }^{2}$ Department of Community Medicine, University of Medical Sciences, Ondo, Nigeria \\ ${ }^{3}$ Ondo State Ministry of Health, Akure, Nigeria \\ ${ }^{4}$ Nigeria Field Epidemiology and Laboratory Training Programme, Abuja, Nigeria \\ Email: ^elvisisere@gmail.com, ^adewaleadejugbagbe@yahoo.com
}

\begin{abstract}
How to cite this paper: Isere, E.E., Adejugbagbe, A.M., Fagbemi, A.T., Fagbemi, S., Famokun, A.G., Omoju, T.O. and Adegbenro, W. (2021) Outcome of Epidemiological Investigation of COVID-19 Outbreak in a South West State of Nigeria, March to August 2020. Open Journal of Epidemiology, 11, 163-177.
\end{abstract}

https://doi.org/10.4236/ojepi.2021.112015

Received: February 16, 2021

Accepted: May 21, 2021

Published: May 24, 2021

Copyright ( 2021 by author(s) and Scientific Research Publishing Inc. This work is licensed under the Creative Commons Attribution International License (CC BY 4.0).

http://creativecommons.org/licenses/by/4.0/ (c) (i) Open Access

\begin{abstract}
Background: On $3^{\text {rd }}$ April 2020, an outbreak of Coronavirus disease-2019 (COVID-19) was confirmed in Ondo State, Southwest Nigeria. Field investigations were conducted by the State Ministry of Health $(\mathrm{MoH})$ to identify and confirm additional cases. This paper provides the outcome of the epidemiological investigation of the outbreak to further guide outbreak response activities. Methods: Field epidemiology methods coordinated by the State Public Health Emergency Operations Center (PHEOC) were used in the outbreak investigation. Suspected cases were reported through the routine Integrated Disease Surveillance and Response (IDSR) network in the State. Also, active case search/finding to communities and health facilities using the operational case definitions was conducted. Furthermore, the state COVID-19 emergency call center was established with toll-free phone number provided to members of the public to call-in to report suspected persons with symptoms consistent with the COVID-19 operational case definition (signal). All cases reported were investigated with nasopharyngeal sample collected and confirmatory testing for COVID-19 done by real-time polymerase chain reaction (RT-PCR) in a national reference laboratory. Information of each case investigated was documented using the COVID-19 case investigation form and COVID-19 line-list which captured socio-demographic characteristics, history of exposure to COVID-19, presenting symptoms, travel history and sample collection details. Data were extracted from the case investigation form and line list and analyzed using SPSS version 20, with a p-value set at $<$ 0.05. Results: A total of 4353 suspected cases were reported and investigated,
\end{abstract}


of which 1316 cases were confirmed between March 19, 2020 and August 9, 2020. The mean age of the confirmed cases was $37.8 \pm 14.8$ years. The highest proportion of COVID-19 cases and deaths occurred in the age group $20-39$ years $(50.6 \%)$ and $\geq 60$ years $(13.5 \%)$, respectively. More males $(52.4 \%)$ were affected than females (45.8\%). There were 404 (30.7\%) healthcare workers infection. About a quarter $(325 ; 24.7 \%)$ of the cases was symptomatic and presented with key symptoms such as cough $(98 / 325 ; 30.2 \%)$ and fever $(74 / 325 ; 22.8 \%)$ during the investigation. A case fatality rate (CFR) of $2.2 \%$ was recorded in 7 of the 17 Local Government Areas (LGAs) where confirmed cases were reported in the State. Most of the confirmed cases, 1169 $(88.8 \%)$ reside in urban LGAs of the State. The epidemic curve shows a propagated pattern of transmission with the outbreak reaching its peak on July 2, 2020. Significantly, higher proportion of death was recorded in the age group $\geq 60$ years $(14 ; 13.5 \%)$ and among males $(26 ; 3.6 \%)(p<0.001)$. Conclusions: Our investigation found high transmission of COVID-19 infection among urban residents (LGAs) and health care workers with high mortality among males in older age group in the State. Hence, we recommend intensified risk communication and use of community structures to ensure compliance with public health COVID-19 preventive protocols including enforcing infection prevention and control compliance, particularly among high-risk groups.

\section{Keywords}

Coronavirus Disease 2019, Outbreak, Epidemiology, Ondo State, Nigeria

\section{Introduction}

Coronavirus disease-2019 (COVID-19) is an infectious disease caused by a newly discovered coronavirus called Severe Acute Respiratory Coronavirus 2 (SARS-CoV2) [1]. The SARS-CoV2 belongs to a family of viruses that cause illness with various symptoms such as pneumonia, fever, breathing difficulty and lung infections [2]. The virus is one of the main pathogens of respiratory infection alongside others such as SARSCoV and Middle East Respiratory Syndrome Coronavirus (MERSCoV) that caused severe respiratory syndrome in humans [3]. The term 2019 novel coronavirus was first used to refer to the virus that affected the lower respiratory tract of patients with pneumonia in a local Huanan South China Seafood market in Wuhan City, China on 29 December 2019 [4] [5]. Afterwards, the World Health Organization (WHO) announced the official name of the 2019 novel coronavirus to be coronavirus disease (COVID-19) [1].

The SARS-CoV2 has been understood to be zoonotic, however, no specific animal association has been identified [6]. Human to human transmission has been proven through small droplets expelled from the nose or mouth when a person with COVID-19 coughs, sneezes, or speaks [7]. The virus has been found to adhere to surfaces which act as fomites for the transmission of the disease [8]. The SARS-CoV2 presents in different ways which range from severe illness and 
mortality to mild symptoms and asymptomatic [9]. Early patterns of COVID-19 transmission have shown a trend similar to SARS and MERS coronaviruses however, unlike other coronaviruses, asymptomatic cases can still transmit the infection, which raises public health concerns [10] [11].

The COVID-19 outbreak is increasing and spreading rapidly globally, with over 20 million cases and 800,000 thousand deaths reported in 216 countries as on $28^{\text {th }}$ August 2020 [12]. Since the report of the index case in Nigeria in February 2020 by the Nigeria Center for Disease Control (NCDC), daily records of confirmed cases have been reported in all states in the country, including Ondo State. As on $28^{\text {th }}$ August 2020, a total of 53, 477 cases and 1011 deaths have been reported in Nigeria, while Ondo State ranked $11^{\text {th }}$ among the states with high confirmed cases in the country [13].

This paper presents the outcome of the epidemiological investigation of COVID-19 outbreak in Ondo State, Nigeria from March to August 2020 to further guide the outbreak response activities.

\section{Materials and Methods}

\subsection{Outbreak Settings}

Ondo State is in the South-West Zone of Nigeria with her capital at Akure. The State is situated between longitudes $40,151 \mathrm{E}$ and $60,001 \mathrm{E}$ of the Greenwich median and latitudes $50,451 \mathrm{~N}$ and $70,451 \mathrm{~N}$, which are to the North of the equator in the Southwestern geopolitical zones of the country. The surface area of the State is approximately 15,317 square kilometers and is bounded by Edo and Delta States on the east, Ogun and Osun States on the west, Ekiti and Kogi States on the north and Bight of Benin and the Atlantic Ocean on the South. The State consists of 18 Local Government Areas (LGAs) and 3 senatorial districts namely Ondo Central, North and South districts; and has a projected population of $5,205,141$ in 2020 with an annual growth rate of $3 \%$ based on the 2006 population census [14]. The basic occupation by a vast majority of the population is farming, while other economic activities include small scale businesses, trading and civil service [15].

\subsection{Field Investigation}

The investigation was conducted as part of outbreak control and response measures hence permission to conduct the study was obtained from the State Ministry of Health (SMoH).

Investigation commenced following an alert from clinicians at a government-owned Hospital, Akure on 30 March 2020 of a suspected case of COVID-19, a 34-year-old male with recent travel history to India. He arrived at Ondo State on 21st March 2020 and presented at the hospital with cough, sore throat and running nose with the onset of symptoms on $23^{\text {rd }}$ March 2020. The State public health emergency Rapid Response Team (RRT) comprising of Commissioner for Health, State Epidemiologist, State and LGA surveillance officers, and health development partners in the state visited the hospital to investigate and imple- 
ment public health response. Nasopharygeal and oropharyngeal samples were collected and tested for COVID-19 and returned positive from the national reference laboratory on the $3^{\text {rd }}$ of April 2020.

The State Public Health Emergency Operation Center (PHEOC) was activated to coordinate the outbreak response. Furthermore, the state COVID-19 emergency call center was established with toll-free phone number provided to members of the public to call-in to report suspected persons with symptoms consistent with the COVID-19 operational case definition (signal) for investigation.

Using the COVID-19 operational case definitions developed by the Nigeria Center for Disease Control, active case search visits/case finding was conducted to communities and health facilities across the 18 local government areas (LGAs) by State RRT to identify additional suspected cases. All public health signals received through the State COVID-19 emergency call center were investigated with nasopharyngeal and oropharyngeal samples collected and transported under reverse cold chain temperatures $\left(2^{\circ} \mathrm{C}\right.$ to $\left.8^{\circ} \mathrm{C}\right)$ to designated national reference laboratory for confirmatory testing for COVID-19 by real-time polymerase chain reaction (RT-PCR).

Furthermore, nasopharyngeal and oropharyngeal samples of close contacts of confirmed COVID-19 cases enrolled for 14-days contact follow-up exercise was collected and tested before they exit the follow-up exercise. Data of all cases investigated were documented using the national COVID-19 case investigation form and State COVID-19 line-list. The information documented were name, age/date of birth, gender, address/settlement and LGA of residence, occupation, clinical symptoms/presentations, date of onset of symptoms, travel history, sample collection details, phone contact and epidemiological exposures. Each case investigated was given an Epidemiological number as a unique identifier.

\subsection{Operational Definitions}

During the onset of the outbreak, three categories of case definitions for COVID-19 were used to guide the outbreak investigations according to the NCDC guidelines [16].

Suspect case: 1) This is a patient with acute respiratory illness (fever and at least one sign/ symptom of respiratory disease (e.g., cough, shortness of breath) and a history of travel to or residence in a country/area or territory reporting local transmission of COVID-19 disease during the 14 days prior to symptom onset; 2) or a patient/health care worker with any acute respiratory illness and has been in contact with a confirmed COVID-19 case in the last 14 days prior to the onset of symptoms; 3 ) or a patient with a severe acute respiratory infection (fever and at least one sign/symptom of respiratory disease (e.g., cough, shortness of breath) and requiring hospitalization and with no other aetiology that fully explains the clinical presentation; 4) or a case for whom testing for COVID-19 is inconclusive.

Confirmed case: A person with laboratory confirmation of COVID-19 infection, irrespective of clinical signs and symptoms.

Probable case: Any suspected case for whom testing for COVID-19 is indeter- 
minate test result or for whom testing was positive on a pan-coronavirus assay.

\subsection{Data Analysis}

The State COVID-19 line-list and case investigation forms of all COVID-19 cases from $19^{\text {th }}$ March to $9^{\text {th }}$ August 2020 were retrieved from the state disease surveillance unit, information on key variables were extracted and exported into SPSS version 20 and analyzed. Descriptive statistics such as frequency table, mean (standard deviation) and charts were used to describe key variables including LGA, age, sex, occupation and education and clinical conditions of cases. The week of report of cases and outcomes was used to generate the epidemic curve. The Chi-square test was used to compare categorical variables including the socio-demographic characteristics, clinical condition and outcome of cases. Two-sided P-values $<0.05$ were considered statistically significant.

\section{Results}

\subsection{Socio-Demographic Characteristics of Cases}

A total of 4353 suspected cases were reported and tested for COVID-19 of which 1316 COVID-19 cases were confirmed, with a case fatality rate of $2.2 \%$ recorded in 7 of the 17 LGAs which reported at least a confirmed case (Figure 1, Table 1). Most of the confirmed cases $(1169 ; 88.8 \%)$, reside in urban areas (LGAs) as shown in Table 1 and Table 2.

Table 1. Distribution of confirmed cases by LGAs of residence in Ondo State March 19 to August 9, 2020.

\begin{tabular}{cccc}
\hline${ }^{*}$ LGA & $\begin{array}{c}\text { Confirmed cases } \\
\mathbf{N}=\mathbf{1 3 1 6}\end{array}$ & $\begin{array}{c}\text { Death } \\
\mathbf{N}=\mathbf{2 9}\end{array}$ & ${ }^{*}$ CFR \\
\hline Akure South & 746 & 14 & $1.9 \%$ \\
Ondo West & 171 & 6 & $3.5 \%$ \\
Okitipupa & 131 & 3 & $2.3 \%$ \\
Owo & 124 & 1 & $0.8 \%$ \\
Akure North & 56 & 1 & $1.8 \%$ \\
Odigbo & 22 & 1 & $4.5 \%$ \\
Akoko North East & 15 & 0 & $0.0 \%$ \\
Ifedore & 11 & 1 & $9.1 \%$ \\
Akoko South West & 9 & 0 & $0.0 \%$ \\
Ose & 7 & 0 & $0.0 \%$ \\
Ile-Oluji/Okeigbo & 7 & 0 & $0.0 \%$ \\
Idanre & 5 & 0 & $0.0 \%$ \\
Akoko North West & 3 & 0 & $0.0 \%$ \\
Ese Odo & 3 & 0 & $0.0 \%$ \\
Ilaje & 3 & 0 & $0.0 \%$ \\
Akoko South East & 2 & 1 & $50.0 \%$ \\
Irele & 1 & 1 & $100.0 \%$ \\
Ondo East & 0 & 0 & $0.0 \%$ \\
\hline
\end{tabular}

${ }^{\star}$ LGA $=$ Local Government LGA = Local Government Area; CFR = Case Fatality Rate. 


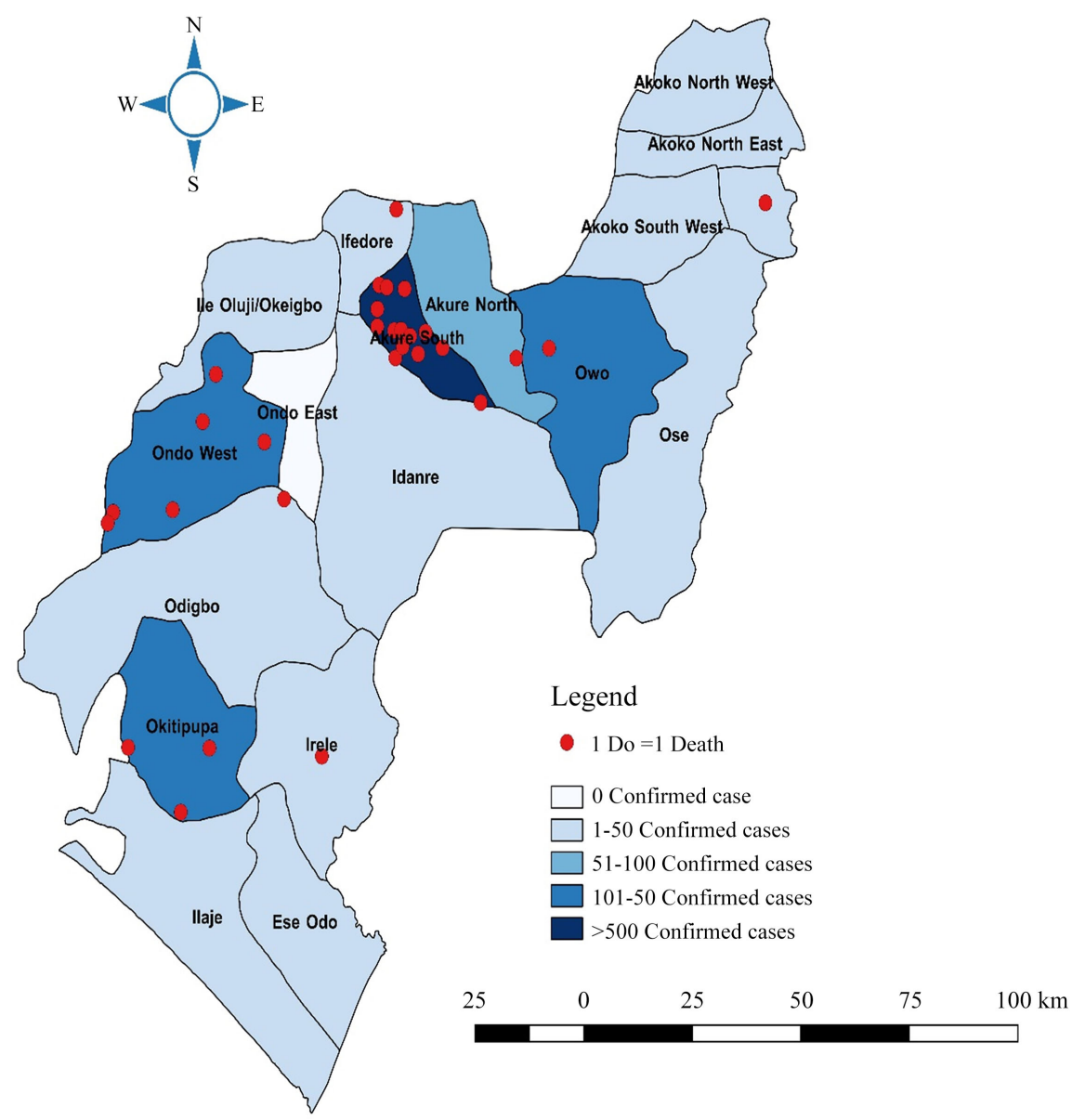

Figure 1. Distribution of suspected and confirmed COVID-19 cases in Ondo state March to August 2020.

Table 2 shows the socio-demographic characteristics of confirmed cases of COVID-19 investigated. Most of the confirmed cases, 1110 (84.3\%) were within the age group 20 to 59 years, with a mean age of $37.8 \pm 14.8$ years. Males (713; $54.2 \%)$ were more affected compare to females $(603 ; 45.8)$ (Table 2). More than three quarters $(1009 ; 76.7 \%)$ of the cases had a tertiary level of education. Health care workers $(404 ; 30.7 \%)$ were most affected compared to other professionals as shown in Table 2.

\subsection{Admission and Clinical Conditions of Confirmed Cases}

From Table 3, 88 (6.7\%) of the confirmed cases were admitted as inpatient, while 325 (24.7\%) were symptomatic. The first symptom reported by cases were as follows; $98(30.2 \%)$ reported cough, fever (74; $22.8 \%)$, headache (30; $9.2 \%)$, runny nose $(39 ; 12.0 \%)$, sore throat $(24 ; 7.4 \%)$ and difficulty in breathing $(15$; $4.6 \%)$.

Figure 2 describes the epidemic curve of the outbreak from March to August 2020. The index case occurred on April 3, 2020. Thereafter, there was a surge in the number of confirmed COVID-19 cases with the outbreak reaching its peak 
on July 2, 2020. Afterwards, fluctuations in the number of cases were observed before a steady decline was recorded between August 3, 2020 and August 9, 2020 .

Table 2. Socio-demographic characteristics of respondents $\mathrm{N}=1316$.

\begin{tabular}{|c|c|c|}
\hline Variable & Frequency & Percentage \\
\hline \multicolumn{3}{|l|}{ Age in years } \\
\hline$<5$ & 18 & 1.4 \\
\hline $5-19$ & 84 & 6.4 \\
\hline $20-39$ & 666 & 50.6 \\
\hline $40-59$ & 444 & 33.7 \\
\hline $60-79$ & 96 & 7.3 \\
\hline$\geq 80$ & 8 & 0.6 \\
\hline \multicolumn{3}{|l|}{ Gender } \\
\hline Male & 713 & 54.2 \\
\hline Female & 603 & 45.8 \\
\hline \multicolumn{3}{|l|}{ Location of cases } \\
\hline Rural & 147 & 11.2 \\
\hline Urban & 1169 & 88.8 \\
\hline \multicolumn{3}{|l|}{ Type of Education } \\
\hline None & 15 & 1.1 \\
\hline Nursery & 8 & 0.6 \\
\hline Primary & 80 & 6.1 \\
\hline Secondary & 204 & 15.5 \\
\hline Tertiary & 1009 & 76.7 \\
\hline \multicolumn{3}{|l|}{ Occupation } \\
\hline Health workers & 404 & 30.7 \\
\hline Businessman and woman & 225 & 17.1 \\
\hline Civil servant & 168 & 12.8 \\
\hline Others & 182 & 13.8 \\
\hline Pupil/Student & 129 & 9.8 \\
\hline Political office Holders & 77 & 5.9 \\
\hline Engineer & 48 & 3.6 \\
\hline Religious/traditional leader & 24 & 1.8 \\
\hline Banker & 24 & 1.8 \\
\hline Security officer & 35 & 2.7 \\
\hline
\end{tabular}


Table 3. Admission and clinical conditions of confirmed cases.

\begin{tabular}{ccc}
\hline & Frequency & Percentage \\
\hline Admitted as inpatient before lab testing & & \\
\hline Yes & 88 & 6.7 \\
No & 1228 & 93.3 \\
\hline Symptomatic & & \\
\hline Yes & 325 & 24.7 \\
No & 991 & 75.3 \\
\hline First symptom reported by respondents (n= 325) & & 30.2 \\
\hline Cough & 98 & 22.8 \\
Fever & 74 & 9.2 \\
Headache & 30 & 12.0 \\
Runny nose & 39 & 7.4 \\
Sore throat/pharyngitis & 24 & 4.6 \\
Difficulty breathing & 15 & 2.7 \\
New loss of taste & 9 & 2.5 \\
New loss of smell & 8 & 2.2 \\
Chest pain & 7 & 1.8 \\
General Body weakness & 67.8 \\
Others & 15 & 2.2 \\
\hline Outcome & & \\
\hline Alive & 29 & \\
Dead & & \\
\hline
\end{tabular}

Others = abdominal pain; chills/sweats; joint pain; inability to walk; Nausea.

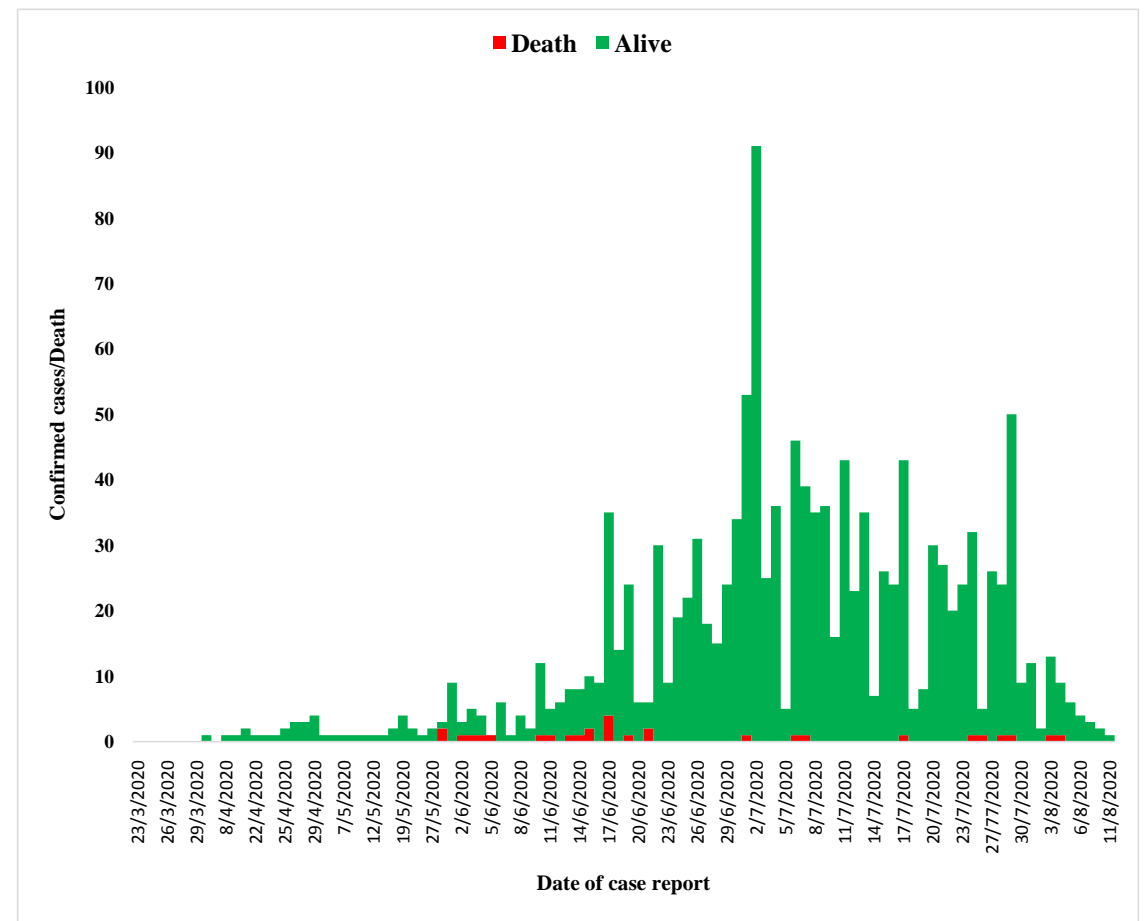

Figure 2. Epi-Curve of confirmed cases of COVID-19 in Ondo State March to August 2020 . 
Association between socio-demographic characteristics, clinical conditions and outcomes of cases

Table 4 below shows the association between the treatment outcomes with characteristics and clinical conditions of cases. A significant proportion of death occurred among cases within the age group 60 years and above (14; 13.5\%) compared to other age groups $(\mathrm{p}<0.001)$. Death occurred among males $(26$; $3.6 \%)$ compared to the females $(3 ; 0.5 \%)(\mathrm{p}<0.001)$. Furthermore, symptomatic cases had higher proportion $(27 ; 8.3 \%)$ of deaths compare to asymptomatic cases (2; $0.2 \%)(\mathrm{P}<0.001)$. Among the symptomatic cases, a high proportion of death was found among those with difficulty in breathing $(3 ; 20 \%)$, fever $(11 ; 14.9 \%)$, new loss of taste $(1 ; 11.1 \%)$, cough $(9 ; 9.2 \%)$ and sore throat $(2 ; 8.3 \%)(\mathrm{P}<0.001)$

Table 4. Association between socio-demographic characteristics and outcomes of cases.

\begin{tabular}{|c|c|c|c|c|}
\hline \multirow{2}{*}{ Variable } & \multicolumn{2}{|l|}{ Outcome } & \multirow{2}{*}{ Total } & \multirow{2}{*}{ P-value } \\
\hline & Dead & Alive & & \\
\hline \multicolumn{5}{|l|}{ Age in years } \\
\hline$<5$ & $0(0.0)$ & $18(100.0)$ & 18 & $<0.001$ \\
\hline $5-19$ & $0(0.0)$ & $84(100.0)$ & 84 & \\
\hline $20-39$ & $2(0.3)$ & $664(99.7)$ & 666 & \\
\hline $40-59$ & $13(2.9)$ & $431(97.1)$ & 444 & \\
\hline$\geq 60$ & $14(13.5)$ & $90(86.5)$ & 104 & \\
\hline \multicolumn{5}{|l|}{ Gender } \\
\hline Male & $26(3.6)$ & $687(96.4)$ & 713 & $<0.001$ \\
\hline Female & $3(0.5)$ & $600(99.5)$ & 603 & \\
\hline \multicolumn{5}{|l|}{ Location of cases } \\
\hline Rural & $5(3.4)$ & $142(96.6)$ & 147 & 0.294 \\
\hline Urban & $24(2.1)$ & 1145 (97.9) & 1169 & \\
\hline \multicolumn{5}{|l|}{ Type of Education } \\
\hline None & $1(6.7)$ & $14(93.3)$ & 15 & 0.630 \\
\hline Nursery & $0(0.0)$ & $8(100.0)$ & 8 & \\
\hline Primary & $3(3.8)$ & $77(96.2)$ & 80 & \\
\hline Secondary & $4(2.0)$ & $200(98.0)$ & 204 & \\
\hline Tertiary & $21(2.1)$ & $988(97.9)$ & 1009 & \\
\hline \multicolumn{5}{|l|}{ Occupation } \\
\hline Health workers & $2(0.5)$ & $402(99.5)$ & 24 & \\
\hline Businessman and woman & $14(6.2)$ & $211(93.8)$ & 225 & \\
\hline Civil servant & $1(0.6)$ & $167(99.4)$ & 168 & $<0.001$ \\
\hline Others & $10(5.5)$ & $172(94.5)$ & 182 & \\
\hline Pupil/Student & $0(0.0)$ & $129(100.0)$ & 129 & \\
\hline Politician & $0(0.0)$ & $77(100.0)$ & 77 & \\
\hline
\end{tabular}




\section{Continued}

\begin{tabular}{|c|c|c|c|c|}
\hline Engineer & $0(0.0)$ & $48(100.0)$ & 48 & \\
\hline Religious/traditional ruler & $2(8.3)$ & $22(91.7)$ & 24 & \\
\hline Banker & $0(0.0)$ & $24(100.0)$ & 24 & \\
\hline Security officer & $0(0.0)$ & $35(100.0)$ & 35 & \\
\hline \multicolumn{5}{|l|}{ Symptomatic } \\
\hline Yes & $27(8.3)$ & $298(91.7)$ & 325 & $<0.001$ \\
\hline No & $2(0.2)$ & $989(99.8)$ & 991 & \\
\hline First symptom & & & $\mathrm{N}=325$ & \\
\hline Cough & $9(9.2)$ & $89(90.8)$ & 98 & \\
\hline Fever & $11(14.9)$ & $63(85.1)$ & 74 & $<0.001$ \\
\hline Headache & $1(3.3)$ & $29(96.7)$ & 30 & \\
\hline Running nose & $0(0.0)$ & $39(100.0)$ & 39 & \\
\hline Sore throat & $2(8.3)$ & $22(91.7)$ & 24 & \\
\hline New loss of taste & $1(11.1)$ & $8(88.9)$ & 9 & \\
\hline Difficulty in breathing & $3(20.0)$ & $12(80.0)$ & 15 & \\
\hline New loss of smell & $0(0.0)$ & $5(100.0)$ & 5 & \\
\hline${ }^{\star}$ Others & $0(0.0)$ & $31(100.0)$ & 31 & \\
\hline
\end{tabular}

* Others = chest pain, diarrheoa, fatigue, joint pain, malaise, nausea, vomiting.

\section{Discussion}

The finding in this investigation that a high proportion of the confirmed COVID-19 cases were males and between the age group of 20 to 59 years is consistent with previous studies in Oyo State, Nigeria [3] and Wuhan, China [17]. The high proportion of COVID-19 infection among the male age group could be attributed to the fact that this is an economically active age group, suggesting a potential role of socio-economic or work-related activities rather than immunological capacity. In the Nigeria system, men are more likely to engage in economic activities outside of the household and potentially become more exposed to SARS-CoV-2 infection than women [18]. Also, Bwire [19], De La Vega et al., [20] and Isere et al., [11] in their studies reported poor compliance and attitude towards COVID-19 preventive measures and protocol such as frequent hand washing, wearing of face mask, and stay at home orders among men compare to women.

Similarly, our investigation shows a high proportion of infection among healthcare workers which is consistent with a previous investigation by Usman et.al., [3]. This might be attributed to poor compliance to COVID-19 IPC protocol by health care workers due to key issues such as knowledge gaps and access to PPEs in the health care settings. This is of serious public health importance as it could potentially enhance disease transmission [21] and further weaken a health system that already struggles with insufficient human resources for health 
[18]. Also, the high proportion of infection among healthcare workers could also be attributed to poor level of preparedness for the COVID-19 outbreak in the health care settings, and this is also in consonance with the report of Elhadi et al., [22].

The epidemic curve of the outbreak suggests a propagated pattern of transmission of the disease. This is consistent with previous COVID-19 outbreak reports and studies in other regions of Nigeria NCDC [23], Usman et al., [3], Elimian et.al., [18] and in China by Chen et al., [24]. The pattern of the outbreak is suggestive of person-to-person transmission which further explains the findings in this investigation that most of the cases (88.8\%) occurred in urban settings where crowded conditions, clustered settlement pattern of the houses and large-scale human interactions due to daily commercial activities could have facilitated the spread of the outbreak [25] [26].

The most common COVID-19 symptoms reported in our investigation were fever and cough. Grant et al., [27] and Tahvildari et al., [28] have reported similar findings from previous studies. Furthermore, the lower proportions of fever and cough reported in this study compared to other studies could be attributed to the fact that our investigation is a population-based study where symptoms were self-reported alongside testing, unlike previous studies where testing was limited to patients on admission at the hospital in the early phase of the outbreak [27] [28]. More importantly, fever which is one of the common symptoms reported in this investigation is often common in endemic febrile illnesses (malaria and Lassa fever) in Ondo State [18]. Hence, co-infection with these diseases could be responsible for the high report of fever as a symptom in this investigation compared to other symptoms.

The low case fatality rate (CFR) found in this study is consistent with that previous reports in the Nigeria [23] and other Africa countries such as South Africa and Senegal [12]. This could be associated with the mild to asymptomatic clinical presentation of most cases in this study who are more likely to recover from the infection [11] [29]. Also, our investigation shows a significantly high mortality rate among cases in the older age group who were mostly male compared to females. This sex-biased mortality could be attributed to sex differences in immune response as females are known to mount more robust innate, cell-mediated, and humoral immune response than males [30]. Sex chromosome constitution could also play an important role in disease outcome. Females have two copies of $\mathrm{X}$ chromosomes while males have one [31] [32] [33]. The $\mathrm{X}$ chromosome contains a high density of immune-related genes. Males and females show a distinct difference in immune system responses with females eliciting stronger immune responses to pathogens [31] [32] [33].

This difference in immune system responses may be a major contributing factor to viral load, disease severity, and mortality [30]. Also, differences in sex hormone milieus could be a determinant of viral infections as estrogen has immunoenhancing effects while testosterone has immunosuppressive effects [30]. 
The sex-specific severity of COVID-19 infection, however, indicates that further research on understanding the sex differences is needed [30].

Some key limitations of this investigation include misclassification bias as most cases were asymptomatic and their clinical presentations were not consistent with the surveillance operational case definition. However, a consistent review of the operational case definition using daily data generated from the field investigation assisted in minimizing misclassification bias. In addition, the data presented in this investigation is a preliminary finding of the outbreak investigation which might change with time as the outbreak is still ongoing. Finally, the epi-curve was generated using the week of report as opposed to the typical use of the date of onset of symptoms. This was because of the asymptomatic clinical status of most of the confirmed cases during the investigation. In addition, social desirability bias is suspected as community perception about the COVID-19 disease might have stigmatized respondents. However, probing questions were asked to ensure correct responses where possible.

\section{Conclusion}

The outcome of this investigation indicates that high transmission among urban residence and health care workers are key public health concerns in the response to the COVID-19 outbreak in Ondo State, Nigeria. Furthermore, high case mortality among the older age groups requires public health intervention. Thus, we recommend intensified risk communication, enhanced surveillance activities, and use of community structures such as community and religious leaders, market and commercial vehicles associations, Ward Development Committee (WDC) and Village Development Committee (VDC) to ensure compliance with public health COVID-19 preventive measures particularly in the urban areas and among those facing a high risk of death. Furthermore, there is a need to prioritize public health interventions including training and vaccination among the vulnerable groups including health care workers who serve as front liners during case investigation, testing and case management.

\section{Authors' Contributions}

Author EEI conceived the study and statistical analysis plan. Author AMA and EEI did the statistical analysis and drafted the first draft of the manuscript under the supervision of ATF, SF, AGF, TOO and WA. All authors contributed to the interpretation of results and writing of the manuscript.

\section{Role of Funding Source}

The study has no funder who played any role in any stage of the study.

\section{Ethical Approval}

No ethical approval required given that the study was included in an outbreak investigation. 


\section{Acknowledgements}

The authors wish to appreciate all health care workers, surveillance officers, public health administrators and other stakeholders on the frontline in response to the COVID-19 outbreak in Ondo State especially field officers who through which the data for this study were generated.

\section{Conflicts of Interest}

The authors declare no conflicts of interest regarding the publication of this paper.

\section{References}

[1] World Health Organization (2020) Novel Coronavirus-China. https://www.who.int/csr/don/12-january-2020-novel-coronavirus-china/en/

[2] Adhikari, S., Meng, S., Wu, Y.J., Mao, Y.P., Ye, R.X., Wang, Q.Z., Sun, C., Sylvia, S., Rozelle, S., Raat, H. and Zhou, H. (2020) Epidemiology, Causes, Clinical Manifestation and Diagnosis, Prevention and Control of Coronavirus Disease (COVID-19) during the Early Outbreak Period: A Scoping Review. Infectious Diseases of Poverty, 9, Article Number: 29. https://doi.org/10.1186/s40249-020-00646-X

[3] Usman, A.B., Ayinde, O., Akinyode, A., Gbolahan, A. and Bello, B. (2020) Epidemiology of Coronavirus Disease 2019 (COVD-19) Outbreak Cases in Oyo State South West Nigeria, March-April 2020. Pan African Medical Journal, 35, Article No. 88. https://doi.org/10.11604/pamj.supp.2020.35.2.23832

[4] Center for Disease Control (2020) Novel Coronavirus, Wuhan, China. https://www.cdc.gov/coronavirus/2019-nCoV/summary.html

[5] Li, Q., Guan, X., Wu, P., Wang, X., Zhou, L., Tong, Y., et al. (2020) Early Transmission Dynamics in Wuhan, China, of Novel Coronavirus-Infected Pneumonia. The New England Journal of Medicine, 382, 1199-1207. https://doi.org/10.1056/NEJMoa2001316

[6] World Health Organization (2020) Novel Coronavirus-Japan (ex-China). https://www.who.int/csr/don/17-january-2020-novel-coronavirus-japan-ex-china/e $\underline{\mathrm{n} /}$

[7] World Health Organization (2020) Q\&A on Coronaviruses (COVID-19). https://www.who.int/emergencies/diseases/novel-coronavirus-2019/question-and-a nswers-hub/q-a-detail/q-a-coronaviruses\#: :text=symptoms

[8] van Doremalen, N., Bushmaker, T., Morris, D.H., Holbrook, M.G., Gamble, A., Williamson, B.N., Tamin, A., et al. (2020) Aerosol and Surface Stability of SARS-CoV-2 as Compared with SARS-CoV-1. The New England Journal of Medicine, 382, 1564-1567. https://doi.org/10.1056/NEJMc2004973

[9] Center for Disease Control (2020) Coronavirus Disease 2019 (COVID-19): Symptoms of Coronavirus.

https://www.cdc.gov/coronavirus/2019-ncov/symptoms-testing/symptoms.html?C DC AA refVal=https\%3A\%2F\%2Fwww.cdc.gov\%2Fcoronavirus\%2F2019-ncov\%2 Fabout\%2Fsymptoms.html

[10] Yu, P., Zhu, J., Zhang, Z., Han, Y. and Huang, L. (2020) A Familial Cluster of Infection Associated with the 2019 Novel Coronavirus Indicating Potential Person-to-Person Transmission during the Incubation Period. Journal of Infectious Diseases, 221, 1757-1761. https://doi.org/10.1093/infdis/jiaa077 
[11] Isere, E.E., Adejugbagbe, A.M., Oladoyin, V., Abiona, S. and Omorogbe, E.N. (2020) Pre-Symptomatic and Asymptomatic COVID-19 Cases in Nigeria Amidst Prevailing Socio-Cultural Beliefs and Practices: Implication for COVID-19 Transmission and Way Forward. Archive of Preventive Medicine, 5, 39-42.

[12] World Health Organization (2020) Weekly Operational Update on COVID-19-28 August 2020.

https://www.who.int/docs/default-source/coronaviruse/situation-reports/wou-28-a ugust-approved.pdf?sfvrsn $=\mathrm{d} 9 \mathrm{e} 49 \mathrm{c} 20 \_2$

[13] Nigeria Centre for Disease Control (2020) An Update of COVID-19 Outbreak in Nigeria.

https://ncdc.gov.ng/diseases/sitreps/?cat=14\&name=An\%20update $\% 20$ of $\% 20 \mathrm{COVI}$ D-19\%20outbreak\%20in\%20Nigeria

[14] National Bureau of Statistics (2020) 2017 Demographic Statistics Bulletin. https://nigerianstat.gov.ng/download/474

[15] Isere, E.E., Fatiregun, A.A., Ilesanmi, O., Ijarotimi, I., Egube, B., Adejugbagbe, A. and Famokun, G. (2018) Lessons Learnt from Epidemiological Investigation of Lassa Fever Outbreak in a South-west State of Nigeria December 2015 to April 2016. PLOS Current Outbreak, 10. https://doi.org/10.1371/currents.outbreaks.bc4396a6650d0ed1985d731583bf5ded

[16] Nigeria Centre for Disease Control (2020) Case Definitions for Coronavirus Disease. https://ncdc.gov.in/WriteReadData/1892s/51329605621586240962.pdf

[17] Wang, D., Yin, Y., Hu, C., Liu, X., Zhang, X., Zhou, S., Jian, M., Xu, H., Prowle, J., $\mathrm{Hu}, \mathrm{B}$., Li, Y. and Peng Z. (2020) Clinical Course and Outcome of 107 Patients Infected with the Novel Coronavirus, SARS-CoV-2, Discharged from Two Hospitals in Wuhan, China. Critical Care, 24, Article No. 188. https://doi.org/10.1186/s13054-020-02895-6

[18] Elimian, K.O., Ochu, C.L., Ilori, E., Oladejo, J., Igumbor E., Steinhardt, L., et al. (2020) Descriptive Epidemiology of Coronavirus Disease 2019 in Nigeria, 27 February-6 June 2020. Epidemiology \& Infection, 148, Article No. e208. https://doi.org/10.1017/S095026882000206X

[19] Bwire, G.M. (2020) Coronavirus: Why Men Are More Vulnerable to Covid-19 than Women? SN Comprehensive Clinical Medicine, 2, 874-876. https://doi.org/10.1007/s42399-020-00341-w

[20] de la Vega, R., Ruíz-Barquín, R., Boros, S. and Szabo, A. (2020) Could Attitudes toward COVID-19 in Spain Render Men More Vulnerable than Women? Global Public Health, 15, 1278-1291. https://doi.org/10.1080/17441692.2020.1791212

[21] Barranco, R. and Ventura, F. (2020) Covid-19 and Infection in Healthcare Workers: an Emerging Problem. The Medico-Legal Journal, 88, 65-66. https://doi.org/10.1177/0025817220923694

[22] Elhadi, M., Msherghi, A., Alkeelani, M., Zorgani, A., Zaid, A., Alsuyihili, A., Buzreg, A., et al. (2020) Assessment of Healthcare Workers' Levels of Preparedness and Awareness Regarding COVID-19 Infection in Low-Resource Settings. American Journal of Tropical Medicine and Hygiene, 103, 828-833.

https://doi.org/10.4269/ajtmh.20-0330

[23] Nigeria Centre for Disease Control (2020) COVID-19 Situation Report 162. https://ncdc.gov.ng/themes/common/files/sitreps/c6bf4e88ec47ad023b2d5c631d03a 49b.pdf

[24] Chen, T., Guo, S. and Zhong, P. (2020) Epidemic Characteristics of the COVID-19 Outbreak in Tianjin, a Well-Developed City in China. American Journal of Infec- 
tion Control, 48, 1068-1073. https://doi.org/10.1016/j.ajic.2020.06.006

[25] World Health Organization-Africa (2020) COVID-19 Pandemic Expands Reach in Africa. https://www.afro.who.int/news/covid-19-pandemic-expands-reach-africa

[26] Neiderud, C.J. (2015) How Urbanization Affects the Epidemiology of Emerging Infectious Diseases. Infection Ecology \& Epidemiology, 5, Article No. 27060. https://doi.org/10.3402/iee.v5.27060

[27] Grant, M.C., Geoghegan, L., Arbyn, M., Mohammed, Z., McGuinness, L., Clarke, E.L. and Wade, R.G. (2020) The Prevalence of Symptoms in 24,410 Adults Infected by the Novel Coronavirus (SARS-CoV-2; COVID-19): A Systematic Review and Meta-Analysis of 148 Studies from 9 Countries. PLoS ONE, 15, e0234765. https://doi.org/10.1371/journal.pone.0234765

[28] Tahvildari, A., Arbabi, M., Farsi, Y., Jamshidi, P., Hasanzadeh, S., Calcagno, T.M., et al. (2020) Clinical Features, Diagnosis, and Treatment of COVID-19: A Systematic Review of Case Reports and Case Series. Frontiers in Medicine, 7, Article No. 231. https://doi.org/10.3389/fmed.2020.00231

[29] Mi, Y., Huanga, T., Zhanga, J., Qin, Q., Gong, Y., Liu, S., Xue, H., Ning, C., Cao, L. and Cao, Y. (2020) Estimating the Instant Case Fatality Rate of COVID-19 in China. International Journal of Infectious Diseases, 97, 1-6. https://doi.org/10.1016/j.ijid.2020.04.055

[30] Pradhan, A. and Olsson, P. (2020) Sex Differences in Severity and Mortality from COVID-19: Are Males More Vulnerable? Biology of Sex Differences. Biology of Sex Differences, 11, Article No. 53. https://doi.org/10.1186/s13293-020-00330-7

[31] Klein, S.L. and Flanagan, K.L. (2016) Sex Differences in Immune Responses. Nature Reviews Immunology, 16, 626-638. https://doi.org/10.1038/nri.2016.90

[32] Meier, A., Chang, J.J., Chan, E.S., Pollard, R.B., Sidhu, H.K., Kulkarni, S., Wen, T.F., Lindsay, R.J., Orellana, L., Mildvan, D., Bazner, S., Streeck, H., Alter, G., Lifson, J.D., Carrington, M., Bosch, R.J., Robbins, G.K. and Altfeld, M. (2009) Sex Differences in the Toll-Like Receptor-Mediated Response of Plasmacytoid Dendritic Cells to HIV-1. Nature Medicine, 15, 955-959. https://doi.org/10.1038/nm.2004

[33] Hewagama, A., Patel, D., Yarlagadda, S., Strickland, F.M. and Richardson, B.C. (2009) Stronger Inflammatory/Cytotoxic T-Cell Response in Women Identified by Microarray analysis. Genes \& Immunity, 10, 509-516.

https://doi.org/10.1038/gene.2009.12 